\title{
К.И. ГРЕВИНГК - ИССЛЕДОВАТЕЛЬ РУССКОГО СЕВЕРА (ДНЕВНИК О ПУТЕШЕСТВИИ ИЗ АРХАНГЕЛЬСКА ПО ПОБЕРЕЖЬЮ ОНЕЖСКОГО ОЗЕРА НА ПОЛУОСТРОВ КАНИН НОС)
}

\section{Юткина Е.В., Смольянинова В.Н., Докучаев А.Я., Лобанов К.В., Лексин А.Б.}

Институт геологии рудных месторождений, петрографии, минералогии и геохимии РАН, Москва dok@igem.ru

Константин Иванович Гревингк (1819-1887) - выдающийся российский геолог, минералог и археолог, доктор философии, профессор. С 1846 г. он являлся хранителем Минералогического музея Императорской академии наук, а в 1848 г. совершил академическую экспедицию в Олонецкую и Архангельскую губернии. В ходе пятимесячной «геогностической» экспедиции он провел междисциплинарные исследования - геологические, археологические, этнографические и культурологические. В результате этой экспедиции ему улыбнулась удача - на восточном берегу Онежского озера, у прибрежных мысов Бесов и Пери, вблизи деревни Бесов Нос, он первым описал «три ранее не известные ученым группы картин», в настоящее время известные как «Онежские петроглифы» [2].

Ныне полевой дневник К.И. Гревингка хранится в архиве Рудно-петрографического музея ИГЕМ РАН [1] (рис. 1).

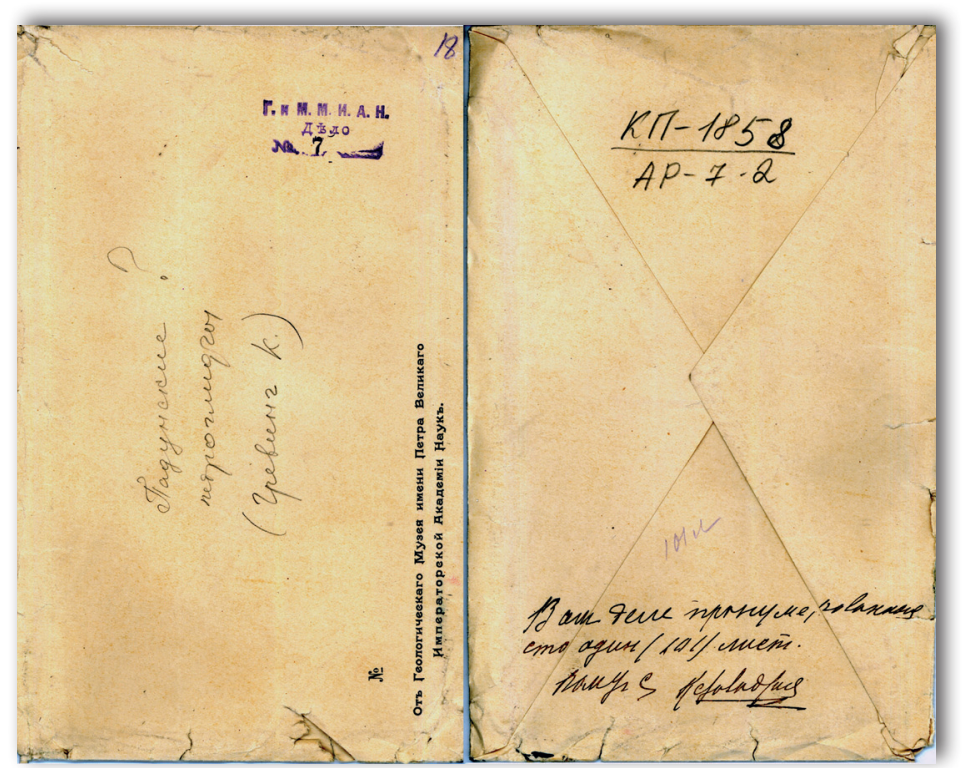

Рис. 1. Конверт, в котором упакован дневник К.И. Гревингка. Архив КП-1858/АР-7-3 Рудно-петрографического музея ИГЕМ РАН [1].

Этот полевой дневник - детальное описание наблюдений на побережье Онежского озера и полуострове Канин, которые молодой ученый вел летом 1848 года. Основное внимание К.И. Гревингк уделил геологическому описанию и изучению территорий, ранее с этой позиции мало изученных. Вместе с тем, исследователь детально документировал все, что казалось ему интересным, в первую очередь, в области природоведения и этнографии Онежского края.

В дневнике, помимо документации петроглифов (рис. 2-3), приведено обилие схематических геологических разрезов и зарисовок с натуры - обнажений, объектов природы, памятников, предметов быта, фамильных знаков, погребальных предметов и многого другого с подробными комментариями (рис. 4).

Дневник составлен на немецком и отчасти на русском языках - в то время официальных языках Императорской академии наук. Имена собственные и географические названия у К.И. Гревингка часто написаны с использованием латиницы и кириллицы, например, Cholmoгоры, MesenЗаозёрская и др. (рис. 2).

Дневник К.И. Гревингка - это не скупой «научный» текст, а подробное, с рисунками и таблицами, «живое» описание зачастую уникальных фактов и явлений, на которые так богат это суровый 


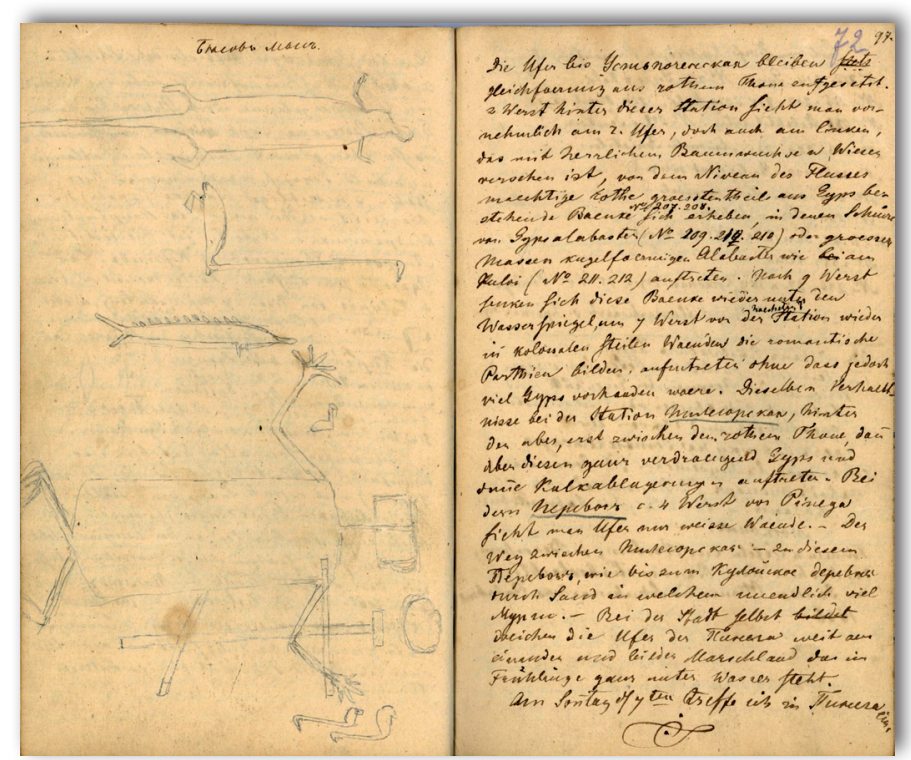

Рис. 2. Зарисовка петроглифов Бесова Мыса. Дневник К.И. Гревингка, стр. 96-97.

Архив КП-1858/АР-7-3 Рудно-петрографического музея ИГЕМ РАН [1].

северный край. Он описывает обряды коренных народов Севера, места поклонения божествам, перечисляет различные виды растительности, названия птиц, которые обитают в местности. В своем дневнике автор занес заинтересовавшие его многочисленные названия местных географических и топонимических объектов - ручьев, населенных пунктов, трактов, холмов, скал, утесов, островов.

Местные жители, лопари (лопляне, они же саамы) и самоеды (самодийские народы -ненцы, энцы, нганасаны, селькупы), сопровождают К.И. Гревингка в его экспедиции и служат ему неисчерпаемым источником исторической, этнографической, фольклорной и лингвистической информации. В частности, в своем дневнике К.И. Гревингк приводит изображения родовых знаков (символов) самоедов (рис. 5) и выясняет их соответствие как к конкретным людям, так и к их отношению к роду. Такие знаки передавались из поколения в поколение и использовались, в частности, как личная подпись.

Представляется очень важной работа ученого над составлением словаря - переводом названий географических объектов, птиц и животных, явлений природы, имен людей, с языка местных племен на русский и немецкий языки (рис. 6).

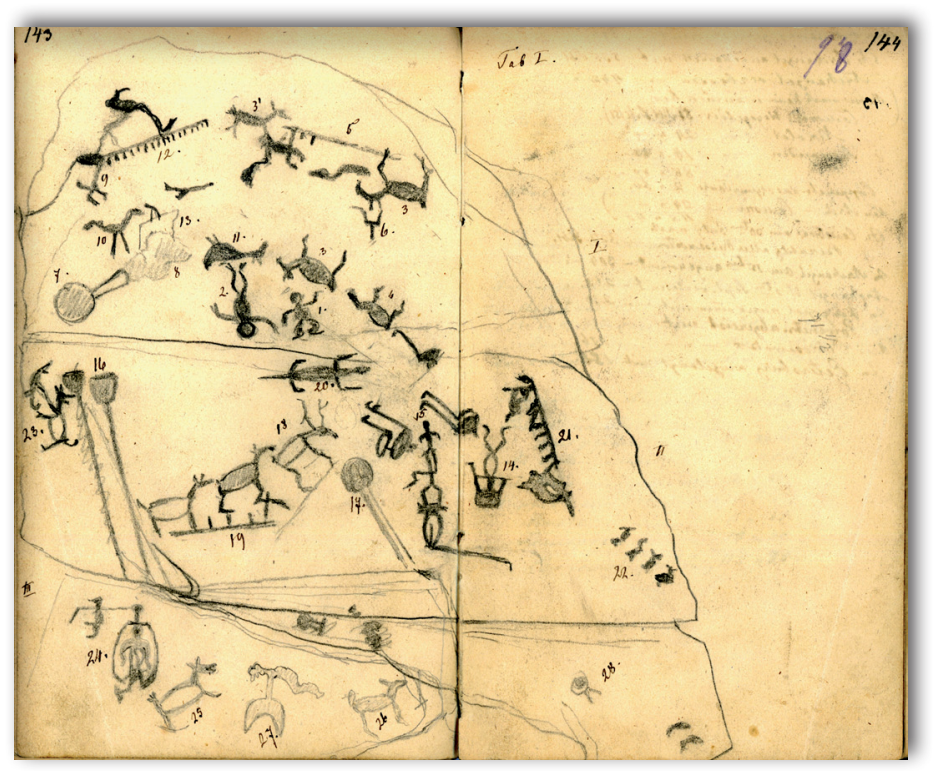

Рис. 3. Бесов Мыс. Зарисовка береговой линии и расположения петроглифов. Вид сверху.

Дневник К.И. Гревингка, стр. 143-144. Архив КП-1858/АР-7-3 Рудно-петрографического музея ИГЕМ РАН [1]. 


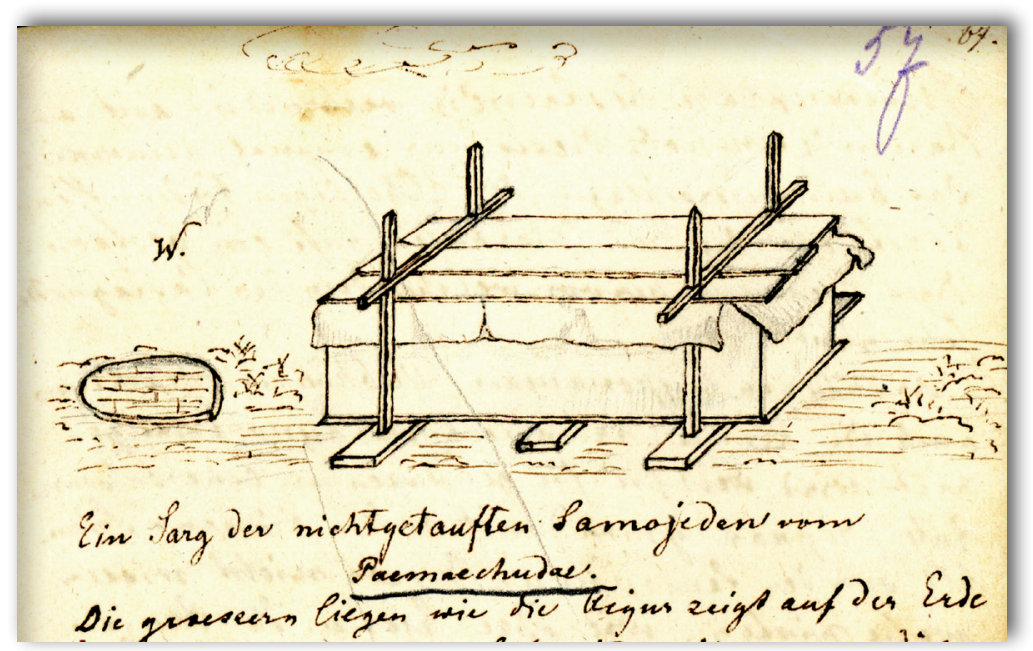

Рис. 4. Саркофаг самоедов (Ein Sarg der nichtgetauften Samojeden vom Paconaechudae).

Дневник К.И. Гревингка, стр. 67 (фрагмент страницы).

Архив КП-1858/АР-7-3 Рудно-петрографического музея ИГЕМ РАН [1].

В научных записях на немецком языке неожиданно встречаются стихотворные строки на русском языке неизвестного автора (рис. 7):

\section{Что на морг Ледовитомь \\ Въ океанг то сердитомъ \\ Есть животныя такія \\ Ужасныя и большія \\ Съ большимами зубами \\ А зовуть то их Моржами \\ Они по морю гуляють \\ И на ледъ потомъ злазають \\ Чтобъ немножко отдохнуть \\ И на солние тамь уснуть}

Впервые выдержки из дневника были опубликованы К.И. Гревингком на немецком языке в 1850 г. в «Известиях физико-математического отделения Санкт-Петербургской Академии наук» [6]. Но не-

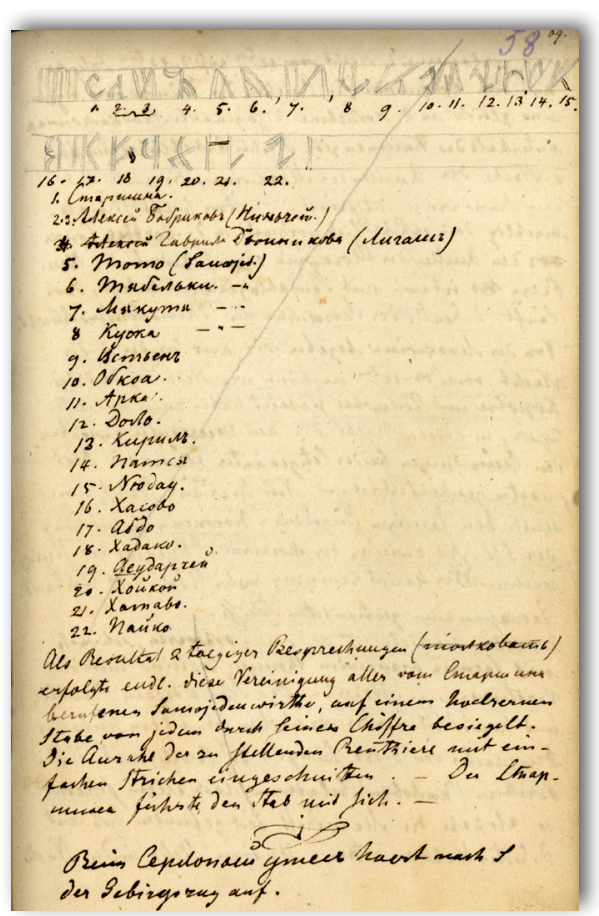
задолго до публикации К.И. Гревингка в журнале «Известия Российского географического общества» появилось сообщение на русском языке учителя Петрозаводской гимназии П. Шведа «Крестовый и Пелий мысы», в которой речь шла о тех же рисунках [3, 4]. В мае 1854 г. К. Гревингк выступил на заседании историко-филологического отделения Академии наук с докладом, впоследствии опубликованном на немецком языке под заголовком «О рисунках на гранитной скале у восточного берега Онежского озера» [5]. По-видимому, П. Швед и К.И. Гревингк описали изображения из разных мест.

По результатам геологического изучения была составлена геологическая карта полуострова Канин, опубликованная в 1892 г. в «Записках Императорской академии наук» [7]. Авторы предисловия (академик А.П. Карпинский, старшие геологи Геологического комитета Ф.Н. Чернышев и

Рис. 5. Изображения родовых знаков (символов) и соответствующих им родовых фамилий. Дневник К.И. Гревингка, стр. 68-69. Архив КП-1858/АР-7-3 Рудно-петрографического музея ИГЕМ РАН [1]. 
С.Н. Никитин) особо выделяют то обстоятельство, что Гревингк делал свои описания с необычайной обстоятельностью и полнотой: «Изследованія на Каниномъ полуостровъ настолько полны и обстоятельны, что сообщаемыхъ въ дневникт фактовъ оказывается достаточно для составленія небольшой геологической карты, приложенной къ настоящему описанію, а также для нғъкоторыхъ общихъ заключеній, которыя мы приводимъ въ кониг дневника. Такіе выводы могли быть сдгланы тъзи сь большею увгоренностью, что пишущій эти строки имгль возможность въ посльдніе годы побывать во многихъ мъстностяхъ, находящихся на пути изсльдованій Гревингка, и могъ убгдиться въ замъчательной полноть и точности приводимыхъ въ дневникг фактическихъ описаній. Если въ дневникг и встречаются нъкоторые пропуски въ наблюденіяхъ по Пинегъ и Кулою, то, очевидно, это завистьло частью отъ поспгшности, съ которою Гревингкъ долженъ быль передвигаться по пути къ Канину, частью же и оть того, что геологи сороковыхъ годовъ многимъ фактамъ придавали, сравнительно, мало значенія. Эти фактическія данныя, добытыл нами лично, мы приводимъ въ видг примъчаній къ соотвљтствующимъ мъстамъ дневника» [7].

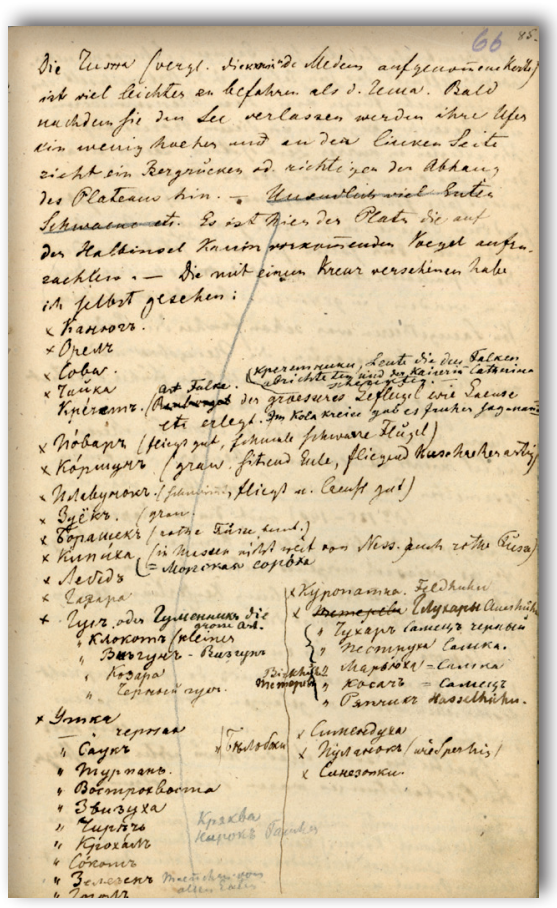

Рис. 6. «Орнитологический словарь». Дневник К.И. Гревингка, стр. 85 (фрагмент страницы). Архив КП-1858/АР-7-3 Руднопетрографического музея ИГЕМ РАН [1].

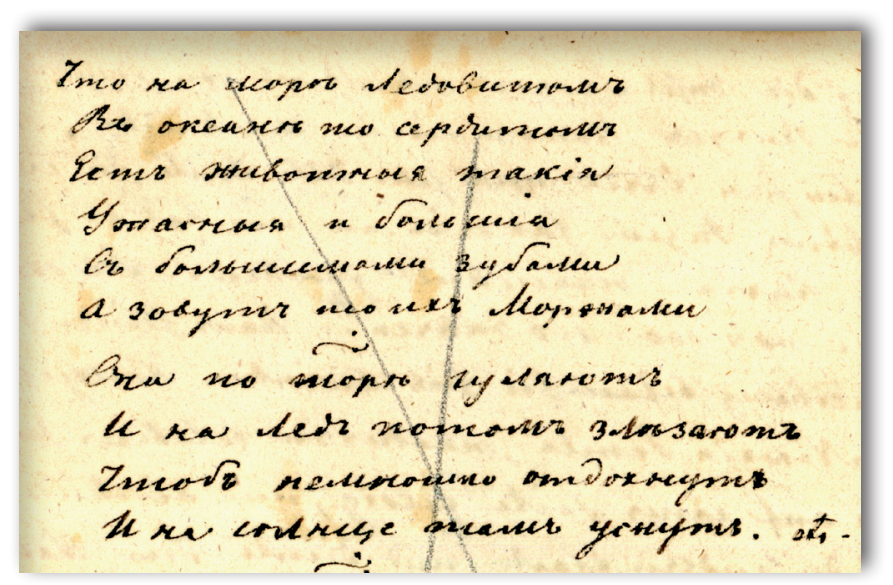

Рис. 7. Поэтические строчки. Дневник К.И. Гревингка, стр. 90 (фрагмент страницы). Архив КП-1858/АР-7-3 Рудно-петрографического музея ИГЕМ РАН [1].

\section{Литература}

1. Архив Рудно-петрографического музея ИГЕМ РАН. КП-1858 / АР-7-2. 101 с.

2. Савватеев Ю.А. Вечные письмена (наскальные изображения Карелии). Петрозаводск: КарНЦ РАН, 2007. $464 \mathrm{c}$.

3. Савватеев Ю.А. Город Пудож и онежские петроглифы // Историко-культурные традиции малых городов Русского Севера. Петрозаводск, 2006. С. 14-33.

4. Швед П. Крестовый и Пелий мысы // Известия Русского географического общества. 1850. Кн. 1. С. 68-72.

5. Grewingk C. Uber die Granit geritzten Bilder gruppen am Ostufer des Onega-Sees // Bull. de la classe de Sciences Hist., Philol. et Polit. l'Acad des Sciences de St. Petersbourg. 1855. T. 12. № 7-8. P. 96-103.

6. Grewingk C. Uber eine in Sommer 1848 unternommene Reise nach der Holbinsel Kanin am nordlichen Eismeere // Bull. de la Classe Physico-Math. de l'Acad des Sciences de St. Petersbourg. 1850. T. 8. P. 44-48.

7. Гревингк К. Путешествие на полуостров Канин // Записки Императорской Академии наук. 1892. Т. :7. Приложение № 11. С. 3. 